Early career teachers' sense of professional agency in the classroom : associations with turnover intentions and perceived inadequacy in teacher-student interaction

\author{
Heikonen, Lauri
}

2017-06

Heikonen , L , Pietarinen , J , Pyhältö , K , Toom , A \& Soini , T 2017 , ' Early career teachers' sense of professional agency in the classroom : associations with turnover intentions and perceived inadequacy in teacher-student interaction ' , Asia - Pacific Journal of Teacher Education , vol. 45 , no. 3 , pp. 250-266 . https://doi.org/10.1080/1359866X.2016.1169505

http://hdl.handle.net/10138/315760

https://doi.org/10.1080/1359866X.2016.1169505

cc_by_nc_nd

acceptedVersion

Downloaded from Helda, University of Helsinki institutional repository.

This is an electronic reprint of the original article.

This reprint may differ from the original in pagination and typographic detail.

Please cite the original version. 


\title{
Early career teachers' sense of professional agency in the classroom: Associations with turnover intentions and perceived inadequacy in teacher-student interaction
}

\begin{abstract}
Teachers' capacity to learn intentionally and responsively in the classroom is particularly vulnerable during the first years in the profession. This study investigated the interrelations between early career teachers' turnover intentions, perceived inadequacy in teacher-student interaction, and sense of professional agency in the classroom. The survey data were collected from 284 in-service teachers with not more than five years of experience and analysed by structural equation modelling (SEM). The results showed that the negative relation between turnover intentions and early career teachers' sense of professional agency was completely mediated by perceived inadequacy in teacher student interaction. The results indicate that experiences of insufficient abilities to solve pedagogically and socially challenging student situations have a crucial effect on early career teacher's capacity for adaptive reflection and active transformation of instruction.
\end{abstract}

Keywords: early career teachers, teacher learning, professional agency, turnover intentions, teacher-student interaction

\section{Introduction}

Teacher turnover has been recognized as a problem worldwide; especially high rates of turnover have been reported among early career teachers (Borman \& Dowling, 2008; Guarino, Santibanez, \& Daley, 2006; Scheopner, 2010). Early career teachers' turnover intentions, referring to consideration of changing ones profession, are not immediate choices made in a particular single event. Rather, turnover intentions are related to problematic 
experiences in teacher education and in-service teaching through which early career teachers perceive themselves as teachers and their work (Hong, 2010; Smethem, 2007). Thus, turnover intentions may affect early career teachers' experience of the everyday interactional practices and competence in the classroom. Teacher-student relationships constitute the core of instruction providing the primary context of both teachers' and students' learning as well as emotionally empowering and draining experiences (Soini, Pyhältö, \& Pietarinen, 2010; Spilt, Koomen, \& Thijs, 2011; Van Eekelen, Vermunt, \& Boshuizen, 2006). It has been shown that experiences in pedagogically and socially challenging situations with students affect teachers' perceived self-efficacy, motivation, work engagement and willingness to learn (Beijaard, 1995; Soini et al., 2010; Spilt et al., 2011).

To enhance student learning, teachers are expected to actively learn in classroom interaction throughout their careers (Borko, 2004; Opfer \& Pedder, 2011; Vermunt \& Endedijk, 2011). This requires teachers' professional agency; in other words, they must have the capacity to intentionally manage new learning in classroom interaction (Pyhältö, Pietarinen, \& Soini, 2012). However, there is a gap in the literature on early career teachers'

professional agency in the classroom and essential related factors (Toom, Karvonen, \& Husu, in review). The gap reflects a low number of empirical studies on early career teacher learning in terms of professional agency and insufficient understanding of the effects of early career teachers' turnover intentions on their professional agency in the classroom. Therefore, this study focuses on the interrelations between early career teachers' turnover intentions, their perceived inadequacy in teacher-student interaction and their sense of professional agency in the classroom.

\section{Theoretical framework}

\subsection{Early career teachers' sense of professional agency in classroom interaction}


Teachers' professional agency is relational by nature and embedded in the professional interactions with students and other members of the school community (Greeno, 2006; Lipponen \& Kumpulainen, 2011). It refers to a capacity that enables teachers to intentionally and responsively manage their own learning in order to enhance student learning in the classroom (Pyhältö et al., 2012). Professional agency consists of teachers’ will and motivation to learn, self-efficacy beliefs about learning and intentional activities towards learning in classroom (Giddens, 1986; Edwards, 2005; Soini, Pietarinen, \& Pyhältö, in press; Turnbull, 2002; 2005). Teachers who experience professional agency perceive themselves as being in control of their everyday pedagogical and practical decisions and actions, which are based on their goals, interests and motivations (Vähäsantanen, Hökkä, Eteläpelto, RaskuPuttonen, \& Littleton, 2008). Furthermore, they use others (e.g. pupils, peers) as resources for learning and provide support for them in their learning (Edwards, 2005; Edwards \& D’Arcy, 2004). This further requires creating and sustaining functional teacher-student relationships, and perceiving instruction as a reciprocal process (Martin \& Dowson, 2009). They should also engage in continuous reflection on teacher-student interaction and intentional transformation of classroom practices (Soini et al., in press).

In the classroom, early career in-service teachers learn by experimenting with new and diverse teaching methods, equipment and environments for teaching, reflecting on their actions, and gathering ideas from others (Hoekstra, Brekelmans, Beijaard, \& Korthagen, 2009; Lohman \& Woolf, 2001; de Vries, Jansen, \& van de Grift, 2013). Experimentation and reflection have been shown to significantly contribute to changes in teachers' beliefs and actions (Bakkenes, Vermunt, \& Wubbels, 2010; Meirink, Meijer, Verloop, \& Bergen, 2009). It has been suggested that at the beginning of their careers, teachers experiment less, because they are more concerned with classroom management issues (Grosemans, Boon, Verclairen, Dochy, \& Kyndt, 2015; Meristo \& Eisenschmidt, 2014). Early career teachers tend to move 
towards traditional teacher-centred teaching methods instead of using innovative teaching methods and are relatively rigid in their classroom behaviour during the first years because of their inexperience in the profession (Flores, 2005; Ng, Nicholas, \& Williams, 2010; Rozelle \& Wilson, 2012; Veenman, 1984). There is also evidence that student teachers become more self-focused than student-focused after their first experiences in teaching (Conway \& Clark, 2003). Primary, secondary and special education teachers have reported different sources of disappointments during their first years of teaching (Marso \& Pigge, 1987), but teacherstudent relationships are the most important source of intrinsic rewards in teaching regardless of the stage taught (Ginns, Heirdsfield, Atweh, \& Watters, 2001; Hargreaves, 2000). Despite the challenges during the first years in the profession, teacher development is not linear. The stage models of teacher development (e.g. Fuller \& Bown, 1975) have been challenged in the research literature for simplifying the development of early career teachers (e.g., Conway \& Clark, 2003).

If early career teachers question their beliefs in what they are doing, their developing professionalism and notions of self as a teacher are challenged (Smethem, 2007). There is evidence that teachers' decisions to leave their schools are affected by their pedagogical goals and values; teachers tend to choose schools where they are able to make progress towards more effective and powerful teaching (Hammerness, 2008). Teachers' sense of professional agency is related to their well-being and commitment to the profession (Eteläpelto, Vähäsantanen, Hökkä, \& Paloniemi, 2013; Pietarinen, Pyhältö, Soini, \& SalmelaAro, 2013; Vähäsantanen et al., 2008). If early career teachers' experiences of collaborative learning with students and colleagues are not rewarding, they are more likely to leave teaching (e.g., Johnson \& Birkeland, 2003). Teachers with no experience in seeking support or giving support to others are less likely to promote students' agency in the classroom (Edwards, 2005; Edwards \& D'Arcy, 2004). All in all, the first years in the profession are 
crucial not only for teachers' wellbeing, but also for their learning (Fresko \& Alhija, 2015). Some early career teachers may decide to leave the profession, some experience difficulties in socially challenging classroom situations, which may challenge their capacity to actively and intentionally develop their classroom practices to enhance student learning (e.g., Eteläpelto, Vähäsantanen, \& Hökkä, 2015).

\subsection{Early career teachers' turnover intentions and perceived inadequacy in teacher-student interaction}

Especially high turnover rates have been found among early career teachers (Borman \& Dowling, 2008; Guarino et al., 2006; Scheopner, 2010). It has been shown that turnover intentions predict actual turnover among employees (Griffeth, Hom, \& Gaertner, 2000). Prior research on teachers has used turnover intentions as indicators to investigate the factors that may lead to turnover and to study the differences between teachers who have considered leaving and the ones who have not considered leaving (e.g., Goddard \& Goddard, 2006; Liu \& Onwuegbuzie, 2012). It has been suggested that societal, cultural, economic, and political factors such as support offered via the systemic structures, appreciation/value for the profession, school leadership, and collegial collaboration may explain the differences in early career teacher turnover between countries (Darling-Hammond \& Rothman, 2011; Heikkinen, Jokinen, \& Tynjälä, 2012). There is evidence that higher salary, student demographics, teacher demographics, better working conditions, experienced burnout and greater intrinsic rewards influence teachers' decisions on whether to leave or remain in the profession (Borman \& Dowling, 2008: Guarino et al., 2006; Scheopner, 2010). The teacher turnover rate in Finland is not as worrying as in some other western countries. Still, 20\% of Finnish comprehensive school teachers have seriously considered changing to another profession; the 
most common reason they give for the change is a desire to develop themselves (Jokinen et al., 2013). It has been suggested that early career teachers who leave teaching have experienced few opportunities for professional growth (Gallant \& Riley, 2014). A reason for this might be that a lack of sense of professional agency combined with challenges in the profession may inhibit teacher learning and progress towards more effective teaching according to personal goals.

Turnover intentions refer to an expressed inclination and a deliberate willingness to change one's profession (Pomaki, DeLongis, Frey, Short, \& Woehrle, 2010). Turnover intentions as conceived future events affect teachers' decisions, motivations and actions in the present (Bandura, 2001). Turnover intentions originate, intensify or fade away in the learning processes in teacher education and in work at school (Hong, 2010). It has been suggested that although teachers' turnover intentions do not always lead to a decision to leave the profession, nonetheless they may affect teachers' efforts and effectiveness (DeAngelis, Wall, \& Che, 2013; Ladd, 2011). Teacher-student interaction constitutes a new context for early career teachers' learning that may challenge the development of their sense of professional agency and even lead to turnover (McCormack, Gore, \& Thomas, 2006). They may experience problems with a lack of support or a clash between expectations and reality; they may have issues with decision making and problem solving; or they may face difficulties in classroom management, in motivating students, and in meeting the needs of individual students (e.g., Le Maistre \& Paré, 2010; Veenman, 1984). Compared to more experienced teachers, early career teachers lack routines and practical knowledge for recognizing, categorizing and predicting problems in classroom interaction as well as strategies to confront the problems through transforming instruction (Berliner, 1986; Wolff, van den Bogert, Jarodzka, \& Boshuizen, 2015). 
Inadequacy in teacher-student interaction refers to teachers' experiences of insufficient competence in challenging situations with students. They may perceive a lack of skills to regulate students' learning or experience constant disappointment due to problematic situations with students (Berliner, 1986). Teacher-student relationships constitute one of the most important sources of the intrinsic rewards of teaching; they are also a main feature of the teacher's profession and a precondition for early career teachers' and students' learning (Beijaard, 1995; Beijaard, Meijer, \& Verloop, 2004; Lasky, 2005). It has been shown that teachers' attributions of difficult classroom situations as either learning experiences or inevitable conflicts, affect their well-being (Hoekstra et al., 2009; Soini et al., in press; de Vries et al., 2013). For example, teachers who have a strong sense of efficacy perceive difficulties in teacher-student relationships as challenges and invest their efforts in solving them, whereas teachers with lower self-efficacy beliefs may think there is not much they can do, which decreases their sense of accomplishment and level of engagement (Aloe, Amo, \& Shanahan, 2014; Hong, 2012). Moreover, there is evidence that teachers who are able to create and sustain positive relationships with students are more likely to stay motivated, enjoy their workplace and commit to the profession (Grayson \& Alvarez, 2008; Jo, 2014).

Despite the shared concern on early career teachers' turnover and the recognized importance of teachers' ongoing professional learning in everyday interactional practices, research on the relationships between early career teachers' turnover intentions, perceived inadequacy in teacher-student interaction and their sense of professional agency in the classroom is insufficient (Spilt et al., 2011).

\section{Aim of the study}

This study aims to gain a better understanding of the connections between early career inservice teachers' sense of professional agency in the classroom, experienced inadequacy in 
teacher-student interaction and their turnover intentions. Based on the previous research on early career teachers' professional learning and teacher turnover intentions, the following three hypotheses were tested:

HY1. Early career teachers' turnover intentions are related to the experienced inadequacy in teacher-student relationships and their sense of professional agency in the classroom (Hong, 2010; 2012; Spilt et al., 2011).

HY2. Early career teachers' experienced inadequacy in teacher-student relationships is related to their sense of professional agency in the classroom (Aloe et al., 2014; Hong, 2012).

HY3. The interrelation between early career teachers' turnover intentions and their sense of professional agency in the classroom is mediated by their experienced inadequacy in teacher-student relationships (Hong, 2010; 2012; Spilt et al., 2011).

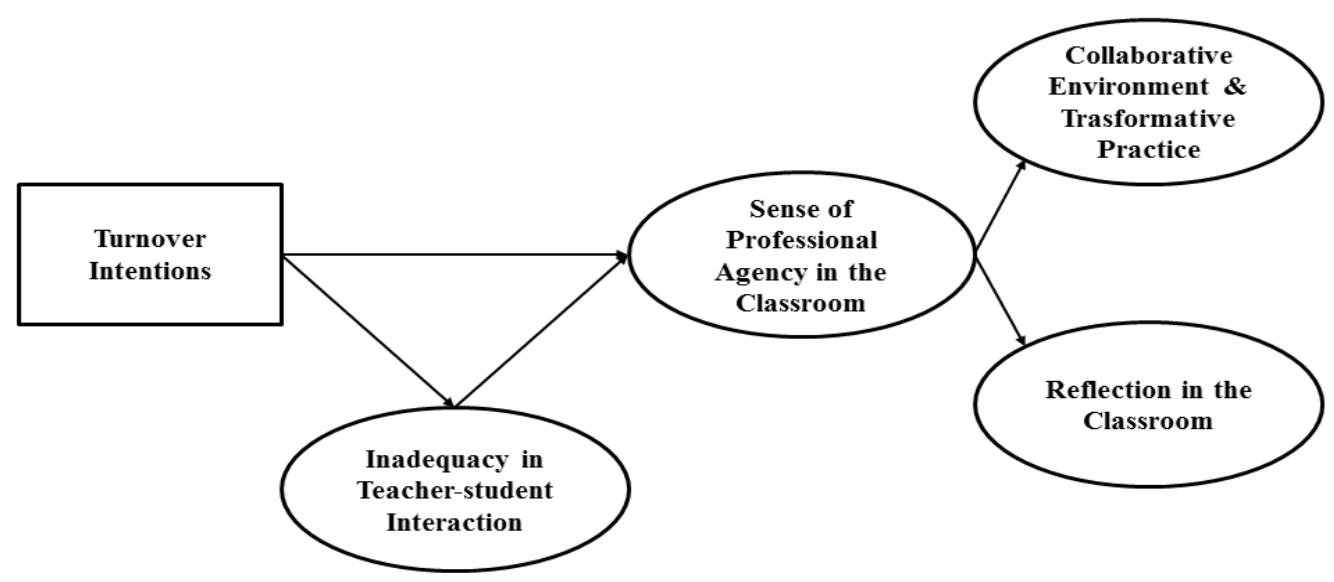

Figure 1

Hypothetical model of the interrelations between early career teachers' turnover 
intentions, experienced inadequacy in teacher-student interaction, and sense of professional agency in classroom.

\section{Method}

\subsection{Research context}

The cohort of Finnish comprehensive school teachers is comprised of primary school teachers, subject teachers and special education teachers. Primary school teachers complete a five-year university Master's degree in education after which they receive a formal qualification to teach in grades 1-6. Subject teachers have a university Master's degree in a subject domain, such as mathematics or English, with additional pedagogical studies in education (60 European Credit Transfer and Accumulation System credits, see European Commission, 2014) that correspond to the work load of one academic year of full-time studies. They teach in grades 7-9 or at an upper-secondary school. Special education teachers have a university Master's degree in special education and they teach in grades 1-9. Teachers work autonomously in making pedagogical decisions and student assessments. In addition, teachers have the responsibility and freedom to plan, implement and revise their teaching within the national curriculum. They also take part in developing the local and school curriculums. Comprehensive schooling is publicly funded and offers a similar basic education for everyone. No separation of students into academic or vocational studies is made during these years. The accountability processes are designed to maintain trust in individual schools (Toom \& Husu, 2012).

\subsection{Participants}


The data consists of early career teachers $(n=284)$, with a maximum of five years of experience. It has been shown that the first five years in teaching are characterized by uncertainty and a fast learning pace, during which teachers construct their professional practice (e.g., Berliner, 1986). The participants included primary $(n=74 ; 26 \%)$, subject $(n=78$; $27 \%)$, and special education teachers $(\mathrm{n}=132 ; 46 \%)$. The mean age of the respondents was 32.5 years ( $\mathrm{SD}=4.76$; $\mathrm{Min} / \mathrm{Max}$ : 25/54 years) and the mean experience they had in teaching was 4.04 ( $\mathrm{SD}=0.96$; Min/Max: 1/5 years). The majority of the participants were women $(n=255 ; 90 \%)$ and the minority were men $(n=28 ; 10 \%)$. The data are from a national sample of 2,310 comprehensive school teachers that was collected by using a probability sampling method $(\mathrm{N}=6,000)$. The survey was sent to 2,000 teachers in each teacher group. All respondents had Master of Arts degrees. The national sample represented the Finnish teacher population well, although female teachers were slightly over-represented (Pietarinen et al., 2013).

\subsection{Measures}

The scales and the factor structures have been validated in prior studies (Pietarinen et al., 2013; Soini et al., in press). Two scales were used to measure early career in-service teachers' professional agency in classroom (10 items) (Soini et al., in press) and inadequacy in teacher-pupil interaction (3 items) (Pietarinen et al., 2013). The scales, items and Cronbach's alphas are presented in Table 1.

The Professional agency in classroom scale (Soini et al., in press) consists of two factors: collaborative environment and transformative practice (6 items) and reflection in classroom (4 items) that constitute a second-order factorial construct. The items measure the central elements of teachers' sense of professional agency, including efficacy beliefs about learning, motivation to learn and intentional acts that facilitate and manage learning in 
the classroom (Edwards, 2005; Soini et al., in press; Turnbull, 2002; 2005). Inadequacy in teacher-pupil interaction consists of three items and is part of the Socio-contextual Teacher Burnout scale (Pietarinen et al., 2013) that draws on Maslach and Jackson's (1981) burnout scale.

Table 1 . The scales and items for exploring the relations between early career teachers' sense of professional agency and perceived inadequacy in teacher-student interaction.

Scales*

Cronbach

$\alpha$

Teacher's professional agency in the classroom

Collaborative environment and transformative practice (CLE)

Cle11: I've been able to build functioning interactive relationships with my pupils.

Cle12: I'm able to create a nice atmosphere together with my students.

Cle13: When planning my work I'm able to utilize the feedback I get from my pupils.

Cle14: I can modify my teaching to adjust to different groups of pupils.

Cle15: I'm able to find teaching methods to engage even the most challenging groups of pupils.

Cle16: I'm able to find ways to support the learning processes of all my pupils.

Reflection in classroom (REF)

Ref21: I still want to learn a lot about teaching.

Ref22: I'd like to understand young people's ways of thinking and acting better.

Ref23: I regularly endeavour to estimate my success in teaching situations.

Ref24: I think we can all learn something in a teaching situation.

Inadequacy in teacher-pupil interaction (INAD)

Inad11: The challenging pupils make me question my abilities as a teacher.

Inad12: I often feel I have failed in my work with pupils.

Inad13: Dealing with problem situations considering my pupils often upsets me.

Note: * The item scale: completely disagree 123456 completely agree 7

The items of these scales were rated on a seven-point Likert scale from one (completely disagree) to seven (completely agree). Cronbach's alphas (Table 1) indicated a sufficient reliability. Teachers' turnover intentions were measured with one item asking if they had considered leaving the teaching profession (Yes/No). This type of item has been used and validated in prior studies as a reliable measure of teacher turnover intention (e.g. Goddard \& Goddard, 2006). Work experience (1-5 years) was included as an independent 
variable to control the effects it may have on the dependent factors. The differences between the three teacher groups were elaborated in the descriptive analysis.

\subsection{Data analyses}

The hypothetical model presented in Figure 1 was tested by means of structural equation modelling (SEM) using MPLUS version 7.11 to explore relations between the latent variables and one observed variable. This approach is used to statistically determine the extent to which the hypothesized model was consistent with the data (Muthén \& Muthén, 1998-2012). The parameters were estimated and standard errors produced using a robust maximum likelihood estimation (MLR) procedure. The goodness-of-fit of the estimated standardized model (Figure 2) was tested with the $\chi^{2}$ test, the Comparative Fit Index (CLI), the Tucker Lewis Index (TLI), the Root Mean Square Error of Approximation (RMSEA) and the Standardized Root Mean Square Residual (SRMR) (Hu \& Bentler, 1999).

\section{Results}

The study investigated the interrelations between early career teachers' turnover intentions, experienced inadequacy in teacher-student interaction, and their sense of professional agency in the classroom. A total of $98(35 \%)$ of the 284 participants reported turnover intentions. The means, standard deviations and correlations between first order latent factors are presented in Table 2.

Table 2. Zero order correlations, means and standard deviations.

\begin{tabular}{llll}
\hline Items & 1. & 2. & 3. \\
\hline
\end{tabular}

1. Inadequacy in teacher-student interaction (INAD) 1.00

2. Collaborative learning environment \&

$\begin{array}{lll}\text { transformative practice (CLE) } & -.56 & 1.00\end{array}$ 


\begin{tabular}{lccc} 
3. Reflection in classroom (REF) & -.19 & .45 & 1.00 \\
\hline Mean & 3.04 & 5.33 & 6.08 \\
SD & 1.28 & 0.75 & 0.65
\end{tabular}

Note: Sum variables were used in descriptive analysis. All correlations were significant at $p$ level $<.01$.

The results confirmed that early career teachers' feelings of insufficient abilities to deal with problematic encounters with students (INAD) correlated negatively $(\mathrm{r}=-.55)$ with self-efficacy beliefs for learning in teacher-student interaction, using students as a resource for learning and actively transforming the teaching practices (CLE). Perceived inadequacy (INAD) also correlated negatively ( $\mathrm{r}=-.19)$ with adaptive reflection in the classroom (REF) (i.e. the will to enhance reciprocal learning by constantly reflecting in teacher-student interaction). Moreover, the correlation between the latent factors of professional agency in the classroom (CLE and REF) was relatively low (.45). This suggests that the seemingly distinct, but related, components of sense of professional agency in the classroom (CLE and REF) can be accounted for by a second-order factor construct (AGENCY) (e.g., Chen, Sousa, $\&$ West, 2005). The correlation between perceived inadequacy in teacher-pupil interaction (INAD) and sense of professional agency in the classroom (AGENCY) followed a similar pattern and level $(-.48, \mathrm{p}<.01)$ in all three groups.

\subsection{Early career teachers' turnover intentions, perceived inadequacy in teacher-pupil interaction and sense of professional agency in the classroom}


The tested model confirmed (H1) that considerations of leaving the teaching profession correlated positively (.35) with an experienced lack of skills and capability of handling challenging teacher-student situations in the classroom. Turnover intentions were associated with questioning one's own abilities and experiencing failure in teacher-student interaction. Moreover, work experience was negatively associated (-.18) with perceiving an inability to handle problematic teacher-student situations. Accordingly, early career teachers' turnover intentions correlated positively and work experience negatively with their perceived inadequacy in teacher-student interaction $\left(\mathrm{R}^{2}=.15\right)$. However, early career teachers' turnover intentions $(-.02, \mathrm{p}=.81)$ and work experience $(.02, \mathrm{p}=.73)$ did not have a statistically significant direct effect on their sense of professional agency in the classroom.

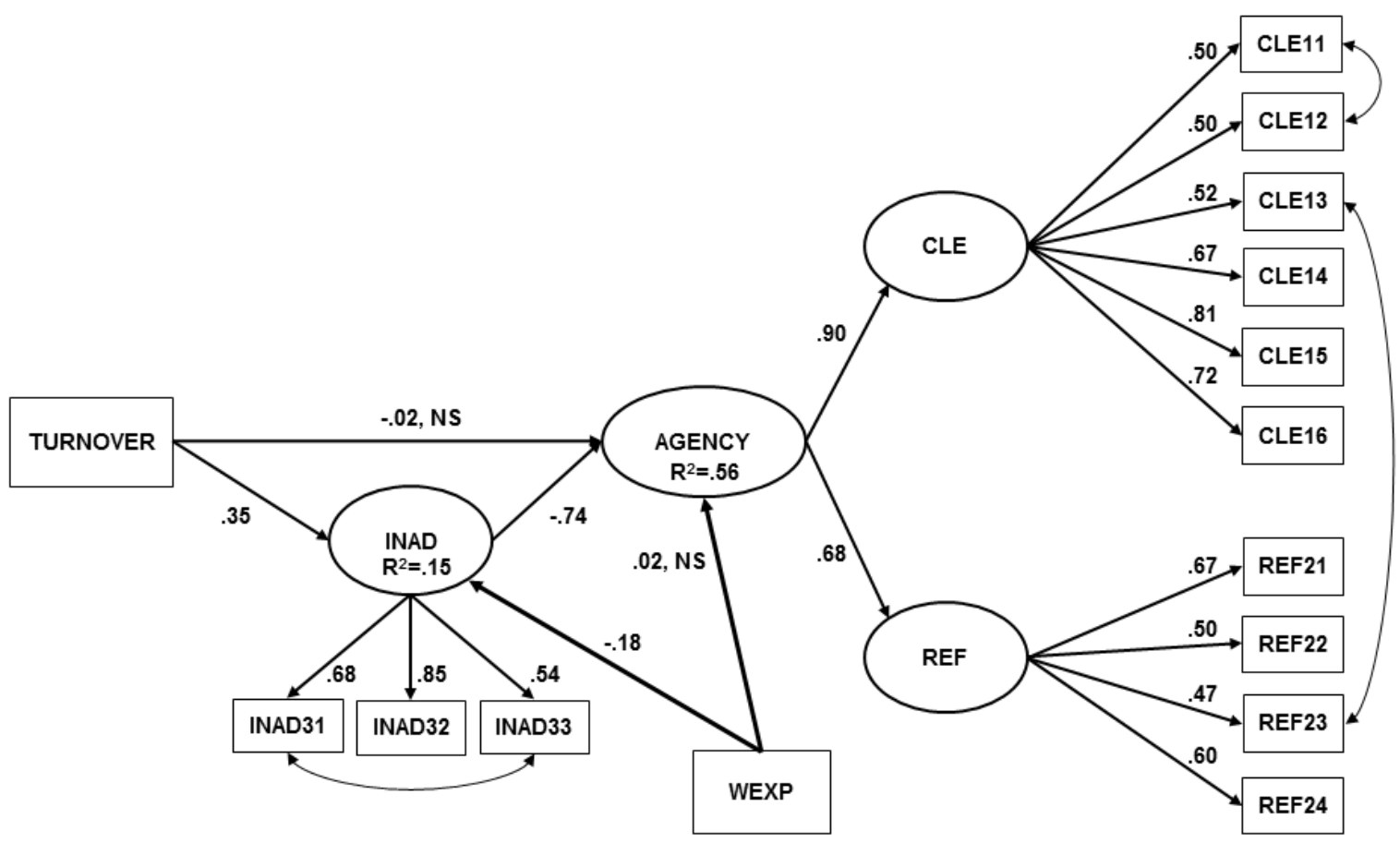

Figure 2. The interrelations between early career teachers' turnover intentions, expected inadequacy in teacher-student interaction, and sense of professional agency in classroom. 
[Standardized model: $\mathrm{X} 2(82, \mathrm{~N}=284)=142.65, \mathrm{p}<.001, \mathrm{CFI}=.94, \mathrm{TLI}=.92, \mathrm{RMSEA}=$ $.05(90 \% \mathrm{CI}=.04-.07), \mathrm{SRMR}=.08$. All parameters were significant at $\mathrm{p}$-level $<.01$, except NS, not significant].

Further investigation confirmed that experienced inadequacy in teacher-student interaction correlated negatively (-.74) with early career teachers' sense of professional agency in the classroom. The tested model showed (H2) that perceiving one's capabilities as insufficient in challenging situations with students was associated with early career teachers' capacity to challenge, manage and change their behaviour and cognitions related to enhancing learning in classroom interaction $\left(\mathrm{R}^{2}=.56\right)$. More concretely, experienced inadequacy in teacher-student interactions was negatively related to early career teachers' self-efficacy, motivation, skills and effort for constructing reciprocal and collaborative learning in the classroom through adaptive reflection, dynamic teaching methods and the use of others as resources for learning.

Teachers' turnover intentions had, through inadequacy in teacher-student interaction, a statistically significant indirect effect (-.26) on their sense of professional agency in the classroom. That is, early career teachers' perceived inadequacy in teacherstudent relationships mediated the negative relation between turnover intentions and their motivation to learn, efficacy beliefs about learning and intentional efforts towards enhancing learning in the classroom. The small and statistically not significant direct effect indicated a complete mediation (H3).

\section{Discussion}

\subsection{Methodological reflection}


A probability sampling method was used to collect a national sample in which teachers at different phases in their careers participated (Pietarinen et al., 2013). The response rate was moderate, but the representativeness of the sample was acceptable. The generalizability of the findings to different socio-cultural contexts should be cautiously considered because the relatively small sample consists only of Finnish early career teachers. Another limitation of this study was that turnover intentions were measured by one item, which did not differentiate the multiple internal and external reasons behind the intentions.

\subsection{Findings in the light of previous literature}

This study aimed to investigate the interrelations between early career teachers' sense of professional agency and their turnover intentions. Our results showed a positive correlation between teacher turnover intentions and perceived inadequacy in teacher-student interaction. This is in line with previous studies (e.g., Hong, 2012) suggesting that there is a difference in the way that stayers and leavers perceive and interpret difficulties in teacher-student interaction. That is, leavers attribute them to their own characteristics, personality and qualities as teacher, while stayers use strategies (e.g., setting emotional boundaries) that prevent them from taking negative situations personally (Hong, 2012). Early in their careers, teachers lack the strategies and routines that make everyday classroom activities function smoothly, which makes them vulnerable to student challenges in classroom interaction, multiple rapid changes in daily work and quick demands related to the responsibilities of teachers' work to guide student learning (Berliner, 1986; Crosswell \& Beutel, 2013; Pietsch \&Williamson, 2010; Wolff et al., 2015). Teachers constantly balance their assessments of positive and negative situations with students. Considering one's vocation seems to bring forth the upsetting experiences of an inability to handle social and pedagogical problems with students. If experiences of success and influence as well as other intrinsic rewards are missing, teachers may feel inadequate at work and be more likely to change schools or leave 
teaching entirely (Johnson \& Birkeland, 2003; Kyriacou \& Kunc, 2007). Early career teachers' work experience was negatively related to perceived inadequacy in teacher-student interaction. The result is in line with the reality shock experienced at the beginning of a teaching career and the rise in confidence for managing classroom situations that is gained through work experience (see Klassen \& Chiu, 2011; Olsen \& Anderson, 2007; Veenman, 1984). However, the correlation between work experience and sense of professional agency was not statistically significant. This indicates that work experience gained in the early phase of a teaching career does not directly affect teachers' self-efficacy, motivation, skills and effort for constructing reciprocal and collaborative learning in the classroom (e.g. Klassen \& Chiu, 2011). More specifically, work experience and instructional routines adopted by teachers decrease the perceived inadequacy in teacher-student interaction that, in turn, seems to be crucial determinant for teacher learning in the classroom.

The present study also showed that early career teachers' perceived inadequacy in teacher-student interaction correlated negatively with their sense of professional agency in the classroom. More specifically, early career teachers' capacity to reflect on interactive and relational instructional processes and intentionally transform classroom practices based on students' initiatives seems to significantly diminish due to perceived inadequacy. This supports previous findings that have highlighted the importance of functional teacher-student relationships for teachers' motivation, job satisfaction, commitment, self-efficacy and wellbeing (Hong, 2010; Soini et al., 2010; Spilt et al., 2011). However, as the relation between self-efficacy beliefs and burnout (Skaalvik \& Skaalvik, 2007), also the relation between teachers' sense of professional agency and perceived inadequacy may be reciprocal. A teacher's reduced sense of professional agency may lead to perceived inadequacy in teacherstudent interaction and thus to turnover intentions. The negative correlation between perceived inadequacy and sense of professional agency was similar in all three teacher 
groups. According to Hargreaves (2000), there are differences in how primary and secondary teachers perceive teacher-student relationships, but they both consider them to be the most important source of enjoyment and motivation. It seems that the destructive friction experienced in challenging situations with students may differ, but the negative effect it has on early career teachers' capacity to intentionally develop classroom practices stands regardless of the group taught.

Teachers' turnover intentions had, through inadequacy in teacher-student interaction, a negative indirect effect on their sense of professional agency in the classroom. Teachers who leave the profession (as the ones who do not) are not a homogeneous group and they differ in terms of teaching practice (Cochran-Smith et al., 2012). These results suggest that teacher-student relationships have an important role in explaining the interrelation between early career teachers' turnover intentions and their capacity to actively enhance learning in the classroom. Early career teachers who consider leaving seem to experience destructive friction in teacher-student interaction, which further negatively reflects on their professional agency. Teachers need strategies and routines to solve problems in socially and pedagogically challenging situations and create functional teacher-student relationships in order to save their resources and emotional investments for the intentional actions directed towards enhancing reciprocal learning in the classroom (Eteläpelto et al., 2015).

Further research on different reasons behind turnover intentions and their relation to early career teachers' professional agency is needed. Teacher turnover is a complex phenomenon that cannot be explained only by the challenges and characteristics of the early career phase, but rather should be studied more holistically. However, it has been shown that teachers with more pedagogical training (e.g., practice teaching, classroom observations, and feedback) are less likely to leave teaching during the first year (Ingersoll, 
Merrill, \& May, 2014). Accordingly, it seems that the diversity of the opportunities to reflect on and experiment with transformative classroom practices not only contributes to early career teachers' sense of professional agency in the classroom, but also increases their ability to cope with inadequacy in teacher-student interaction; thus, they maintain engagement to the profession.

Longitudinal research capturing teacher preparation and the transition into the classroom is required to investigate elements of teacher learning that have a buffering effect on turnover. This would provide teachers, schools, and teacher educators the opportunity to anticipate and react to the demands faced during the early years in the classroom. Further investigation is also required on learning-oriented classroom management strategies that would provide early career teachers occasions for active learning in classroom interaction (Grosemans et al., 2015; Leroux \& Théorêt, 2014; Wolff et al., 2015). Classroom management as a one-sided matter of discipline does not match with early career teacher's ideal of learning in the classroom. Further information is also necessary on the problematic interactional situations that early career teachers encounter in the classroom. How they interpret, solve and reflect on them and do they do so with students? These problem-solving strategies focusing on the classroom dynamics with students could provide teachers with the opportunities to construct professional agency in the classroom.

\subsection{Implications for teacher education and teacher professional learning}

The issue of teacher turnover, turnover intentions and ways to cope with emotional classroom experiences should be addressed already in teacher education programs and in safe surroundings with peers in schools (Fresko \& Alhija, 2015).Teacher educators and mentors should guide early career teachers towards reciprocal learning in teacher-student interaction, facing socially and pedagogically challenging situations as an opportunity for professional 
discovery instead of survival, and developing strategies and routines for classroom work that make room for adaptive reflection and active transformation of classroom practices (Leroux \& Théorêt, 2014). The challenge is to provide student teachers with experiences of deep collaboration in a school context with a continuity that would enable them to perceive the meaning of peer learning in creating functional teacher-student relationships and developing everyday problem-solving strategies (see Vangrieken, Dochy, Raes, \& Kyndt, 2015). Furthermore, early career teachers in schools should be provided with structures for nonthreatening analysis of practice in the rapid pace of classroom work, including possibilities for co-reflections on both positive and negative classroom situations aiming to explore functional and alternative classroom practices (Castro, Kelly, \& Shih, 2010; Chubbuck, Clift, Allard, \& Quinlan, 2001). There is evidence, that school principals have a vital role in supporting early career teachers by fostering collaboration in schools (Long et al., 2012). In different countries, the approaches of mentoring programs differ and have been characterized to consist of support, supervision and collaborative self-development (Kemmis, Heikkinen, Fransson, Aspfors, \& Edwards-Groves, 2014). In Finland, mentoring programs are not mandatory or evaluative. Recently, these support practices have been developed towards peer group mentoring (Geeraerts, Tynjälä, Heikkinen, Markkanen, Pennanen, \& Gijbels, 2015). In these teacher learning processes, involving students as accountable others could have a buffering effect on teachers' turnover intentions or perceived inadequacy; thus, teachers' capacity to orchestrate meaningful learning for all could be empowered.

\section{Disclosure statement}

No potential conflict of interest was reported by the authors.

Funding 
This work was supported by the Academy of Finland [grant number 1259489]; the EU Lifelong Learning Programme [grant number 526318-LLP-1-2012-1-EE-COMENIUSCMP]; and the Finnish Academy of Science and Letters [grant Jutikkala] awarded to Lauri Heikonen.

\section{Notes on contributors}

Lauri Heikonen is a $\mathrm{PhD}$ student in the Department of Teacher Education, University of Helsinki. His research interests are in pre-service and early career in-service teacher learning in classroom interaction.

Janne Pietarinen is a professor in the School of Applied Educational Science and Teacher Education, University of Eastern Finland. His research interests are in the educational transitions, pupils and teachers learning and well-being in the context of sustainable school development.

Kirsi Pyhältö is a Professor in the Faculty of Educational Sciences, University of Oulu. She works also as a Research Director in the Center for Research and Development of Higher Education at the University of Helsinki.

Auli Toom, is a Professor (acting) in the Department of Teacher Education, University of Helsinki. Her major research interests are teacher's pedagogical knowing, teacher agency and teacher education as well as scholarship of teaching and learning in the context of higher education.

Dr. Tiina Soini is a research director in the School of Education, University of Tampere. Her research interests are in the learning and well-being of educational communities, with special focus on teacher communities in comprehensive school. 


\section{ORCID}

Auli Toom http://orcid.org/0000-0002-3261-3376

References:

Aloe, A. M., Amo, L. C., \& Shanahan, M. E. (2014). Classroom Management Self-Efficacy and Burnout: A Multivariate Meta-analysis. Educational Psychology Review, 26(1), 101126.

Bakkenes, I., Vermunt, J. D., \& Wubbels, T. (2010). Teacher learning in the context of educational innovation: Learning activities and learning outcomes of experienced teachers. Learning and Instruction, 20(6), 533-548.

Bandura, A. (2001). Social cognitive theory: An agentic perspective. Annual Review of Psychology, 52(1), 1-26.

Beijaard, D. (1995). Teachers' prior experiences and actual perceptions of professional identity. Teachers and Teaching: Theory and Practice, 1(2), 281-294.

Beijaard, D., Meijer, P. C., \& Verloop, N. (2004). Reconsidering research on teachers' professional identity. Teaching and Teacher Education, 20(2), 107-128.

Berliner, D. C. (1986). In pursuit of the expert pedagogue. Educational Researcher, 5-13.

Borko, H. (2004). Professional development and teacher learning: Mapping the terrain. Educational Researcher, 33(8), 3-15.

Borman, G. D., \& Dowling, N. M. (2008). Teacher attrition and retention: A meta-analytic and narrative review of the research. Review of Educational Research, 78(3), 367-409. 
Castro, A. J., Kelly, J., \& Shih, M. (2010). Resilience strategies for new teachers in highneeds areas. Teaching and Teacher Education, 26(3), 622-629.

Chen, F. F., Sousa, K. H., \& West, S. G. (2005). Teacher's corner: Testing measurement invariance of second-order factor models. Structural equation modeling, 12(3), 471-492.

Chubbuck, S. M., Clift, R. T., Allard, J., \& Quinlan, J. (2001). Playing it safe as a novice teacher implications for programs for new teachers. Journal of Teacher Education, 52(5), 365-376.

Cochran-Smith, M., McQuillan, P., Mitchell, K., Terrell, D. G., Barnatt, J., D’Souza, L., ... Gleeson, A. M. (2012). A longitudinal study of teaching practice and early career decisions: A cautionary tale. American Educational Research Journal, 49(5), 844-880.

Conway, P. F., \& Clark, C. M. (2003). The journey inward and outward: A re-examination of Fuller's concerns-based model of teacher development. Teaching and Teacher Education, 19(5), 465-482.

Crosswell, L., \& Beutel, D. (2013). A bridge over troubling waters: A snapshot of teacher graduates' perceptions of their ongoing professional learning needs. Asia-Pacific Journal of Teacher Education, 41(2), 144-158.

Darling-Hammond, L., \& Rothman, R. (2011). Lessons learned from Finland, Ontario, and Singapore. In L. Darling-Hammond \& R. Rothman (Eds.), Teacher and leader effectiveness in high-performing education systems (pp. 1-13). Stanford, CA: The Alliance for Excellent Education. 
DeAngelis, K. J., Wall, A. F., \& Che, J. (2013). The impact of pre-service preparation and early career support on novice teachers' career intentions and decisions. Journal of Teacher Education, 64(4), 338-355.

Edwards, A. (2005). Relational agency: Learning to be a resourceful practitioner. International Journal of Educational Research, 43(3), 168-182.

Edwards, A., \& D'Arcy, C. (2004). Relational agency and disposition in sociocultural accounts of learning to teach. Educational Review, 56(2), 147-155.

Eteläpelto, A., Vähäsantanen, K., \& Hökkä, P. (2015). How do novice teachers in Finland perceive their professional agency? Teachers and Teaching: Theory and Practice, 21(6), 660-680.

Eteläpelto, A., Vähäsantanen, K., Hökkä, P., \& Paloniemi, S. (2013). What is agency? Conceptualizing professional agency at work. Educational Research Review, 10, 45-65.

European Commission. (2014). European Credit Transfer and Accumulation System (ECTS). Retrieved from http://ec.europa.eu/education/tools/ects_en.htm

Flores, M. A. (2005). Mapping new teacher change: Findings from a two-year study. Teacher Development, 9(3), 389-412.

Fuller, F., \& Bown, O. (1975). Becoming a teacher. In Ryan, K. Seventy-fourth year book of the National Society for the Study of Education: Pt. 2. Teacher Education. Chicago, IL: University of Chicago 
Fresko, B., \& Alhija, N.-A. F. (2015). Induction seminars as professional learning communities for beginning teachers. Asia-Pacific Journal of Teacher Education, 43(1), $36-48$.

Gallant, A., \& Riley, P. (2014). Early career teacher attrition: new thoughts on an intractable problem. Teacher Development, 18(4), 562-580.

Geeraerts, K., Tynjälä, P., Heikkinen, H. L., Markkanen, I., Pennanen, M., \& Gijbels, D. (2014). Peer-group mentoring as a tool for teacher development. European Journal of Teacher Education, 38(3), 1-20.

Ginns, I., Heirdsfield, A., Atweh, B., \& Watters, J. J. (2001). Beginning teachers becoming professionals through action research. Educational Action Research, 9(1), 111-133.

Grosemans, I., Boon, A., Verclairen, C., Dochy, F., \& Kyndt, E. (2015). Informal learning of primary school teachers: Considering the role of teaching experience and school culture. Teaching and Teacher Education, 47, 151-161.

Giddens, A. (1986). Action, subjectivity, and the constitution of meaning. Social Research, $529-545$.

Goddard, R., \& Goddard, M. (2006). Beginning teacher burnout in Queensland schools: Associations with serious intentions to leave. The Australian Educational Researcher, $33(2), 61-75$.

Grayson, J. L., \& Alvarez, H. K. (2008). School climate factors relating to teacher burnout: A mediator model. Teaching and Teacher Education, 24(5), 1349-1363. 
Greeno, J. G. (2006). Authoritative, accountable positioning and connected, general knowing: Progressive themes in understanding transfer. The Journal of the Learning Sciences, 15(4), 537-547.

Griffeth, R. W., Hom, P. W., \& Gaertner, S. (2000). A meta-analysis of antecedents and correlates of employee turnover: Update, moderator tests, and research implications for the next millennium. Journal of Management, 26(3), 463-488.

Guarino, C. M., Santibanez, L., \& Daley, G. A. (2006). Teacher recruitment and retention: A review of the recent empirical literature. Review of Educational Research, 76(2), 173208.

Hammerness, K. (2008). "If you don't know where you are going, any path will do": The role of teachers' visions in teachers' career paths. The New Educator, 4(1), 1-22.

Hargreaves, A. (2000). Mixed emotions: Teachers' perceptions of their interactions with students. Teaching and teacher education, 16(8), 811-826.

Heikkinen, H., Jokinen, H., \& Tynjälä, P. (2012). Teacher education and development as lifelong and lifewide learning. In H. Heikkinen, H. Jokinen, \& P. Tynjälä (Eds.), Peergroup mentoring for teacher development (pp. 3-30). London, UK: Routledge.

Hoekstra, A., Brekelmans, M., Beijaard, D., \& Korthagen, F. (2009). Experienced teachers' informal learning: Learning activities and changes in behavior and cognition. Teaching and Teacher Education, 25(5), 663-673.

Hong, J. Y. (2010). Pre-service and beginning teachers' professional identity and its relation to dropping out of the profession. Teaching and Teacher Education, 26(8), 1530-1543. 
Hong, J. Y. (2012). Why do some beginning teachers leave the school, and others stay? Understanding teacher resilience through psychological lenses. Teachers and Teaching: Theory and Practice, 18(4), 417-440.

Hu, L. T., \& Bentler, P. M. (1999). Cutoff criteria for fit indexes in covariance structure analysis: Conventional criteria versus new alternatives. Structural Equation Modeling: A Multidisciplinary Journal, 6(1), 1-55.

Ingersoll, R., Merrill, L., \& May, H. (2014). What are the effects of teacher education and preparation on beginning teacher attrition? Research Report (\#RR-82). Philadelphia: Consortium for Policy Research in Education, University of Pennsylvania.

Jo, S. H. (2014). Teacher commitment: Exploring associations with relationships and emotions. Teaching and Teacher Education, 43, 120-130.

Johnson, S. M., \& Birkeland, S. E. (2003). Pursuing a "sense of success": New teachers explain their career decisions. American Educational Research Journal, 40(3), 581-617.

Jokinen, H., Taajamo, M., Miettinen, M., Weissmann, K., Honkimäki, S., Valkonen, S., \& Välijärvi, J. (2013). Pedagoginen asiantuntijuus liikkeessä -hankkeen tulokset [Mobility among pedagogical experts -Research findings]. University of Jyväskylä. Finnish Institute of Educational Research. Reports, 50.

Kemmis, S., Heikkinen, H. L., Fransson, G., Aspfors, J., \& Edwards-Groves, C. (2014). Mentoring of new teachers as a contested practice: Supervision, support and collaborative self-development. Teaching and Teacher Education, 43, 154-164. 
Klassen, R. M., \& Chiu, M. M. (2011). The occupational commitment and intention to quit of practicing and pre-service teachers: Influence of self-efficacy, job stress, and teaching context. Contemporary Educational Psychology, 36(2), 114-129.

Kyriacou, C., \& Kunc, R. (2007). Beginning teachers' expectations of teaching. Teaching and Teacher Education, 23(8), 1246-1257.

Ladd, H. F. (2011). Teachers' perceptions of their working conditions: How predictive of planned and actual teacher movement? Educational Evaluation and Policy Analysis, $33(2), 235-261$.

Lasky, S. (2005). A sociocultural approach to understanding teacher identity, agency and professional vulnerability in a context of secondary school reform. Teaching and Teacher Education, 21(8), 899-916.

Le Maistre, C., \& Paré, A. (2010). Whatever it takes: How beginning teachers learn to survive. Teaching and Teacher Education, 26(3), 559-564.

Leroux, M., \& Théorêt, M. (2014). Intriguing empirical relations between teachers' resilience and reflection on practice. Reflective Practice, 15(3), 289-303.

Lipponen, L., \& Kumpulainen, K. (2011). Acting as accountable authors: Creating interactional spaces for agency work in teacher education. Teaching and Teacher Education, 27(5), 812-819.

Liu, S., \& Onwuegbuzie, A. J. (2012). Chinese teachers' work stress and their turnover intention. International Journal of Educational Research, 53, 160-170. 
Lohman, M. C., \& Woolf, N. H. (2001). Self-initiated learning activities of experienced public school teachers: Methods, sources, and relevant organizational influences. Teachers and Teaching: Theory and Practice, 7(1), 59-74.

Long, J. S., McKenzie-Robblee, S., Schaefer, L., Steeves, P., Wnuk, S., Pinnegar, E., \& Clandinin, D. J. (2012). Literature review on induction and mentoring related to early career teacher attrition and retention. Mentoring \& tutoring: partnership in learning, 20(1), 7-26.

Marso, R. N., \& Pigge, F. L. (1987). Differences between self-perceived job expectations and job realities of beginning teachers. Journal of Teacher Education, 38(6), 53-56.

Martin, A. J., \& Dowson, M. (2009). Interpersonal relationships, motivation, engagement, and achievement: Yields for theory, current issues, and educational practice. Review of Educational Research, 79(1), 327-365.

Maslach, C., \& Jackson, S. E. (1981). The measurement of experienced burnout. Journal of Organizational Behavior, 2(2), 99-113.

McCormack, A., Gore, J., \& Thomas, K. (2006). Early career teacher professional learning. Asia-Pacific Journal of Teacher Education, 34(1), 95-113.

Meirink, J. A., Meijer, P. C., Verloop, N., \& Bergen, T. C. M. (2009). Understanding teacher learning in secondary education: The relations of teacher activities to changed beliefs about teaching and learning. Teaching and Teacher Education, 25(1), 89-100.

Meristo, M., \& Eisenschmidt, E. (2014). Novice teachers' perceptions of school climate and self-efficacy. International Journal of Educational Research, 67, 1-10. 
Muthén, L.K. and Muthén, B.O. (1998-2012). Mplus User's Guide. Seventh Edition. Los Angeles, CA: Muthén \& Muthén.

Ng, W., Nicholas, H., \& Williams, A. (2010). School experience influences on pre-service teachers' evolving beliefs about effective teaching. Teaching and Teacher Education, 26(2), 278-289.

Olsen, B., \& Anderson, L. (2007). Courses of action: A qualitative investigation into urban teacher retention and career development. Urban Education, 42(1), 5-29.

Opfer, V. D., \& Pedder, D. (2011). Conceptualizing teacher professional learning. Review of Educational Research, 81(3), 376-407.

Pietarinen, J., Pyhältö, K., Soini, T., \& Salmela-Aro, K. (2013). Reducing teacher burnout: A socio-contextual approach. Teaching and Teacher Education, 35, 62-72.

Pietsch, M., \& Williamson, J. (2010). 'Getting the pieces together': Negotiating the transition from pre-service to in-service teacher. Asia-Pacific Journal of Teacher Education, 38(4), $331-344$.

Pomaki, G., DeLongis, A., Frey, D., Short, K., \& Woehrle, T. (2010). When the going gets tough: Direct, buffering and indirect effects of social support on turnover intention. Teaching and Teacher Education, 26(6), 1340-1346.

Pyhältö, K., Pietarinen, J., \& Soini, T. (2012). Do comprehensive school teachers perceive themselves as active professional agents in school reforms? Journal of Educational Change, 13(1), 95-116. 
Rozelle, J. J., \& Wilson, S. M. (2012). Opening the black box of field experiences: How cooperating teachers' beliefs and practices shape student teachers' beliefs and practices. Teaching and Teacher Education, 28(8), 1196-1205.

Scheopner, A. J. (2010). Irreconcilable differences: Teacher attrition in public and catholic schools. Educational Research Review, 5(3), 261-277.

Skaalvik, E. M., \& Skaalvik, S. (2007). Dimensions of teacher self-efficacy and relations with strain factors, perceived collective teacher efficacy, and teacher burnout. Journal of Educational Psychology, 99(3), 611.

Smethem, L. (2007). Retention and intention in teaching careers: will the new generation stay? Teachers and Teaching: Theory and Practice, 13(5), 465-480.

Soini, T., Pietarinen, J. \& Pyhältö, K. (in press). What if teachers learn in the classroom? Teacher Development.

Soini, T., Pyhältö, K., \& Pietarinen, J. (2010). Pedagogical well-being: Reflecting learning and well-being in teachers' work. Teachers and Teaching: theory and practice, 16(6), 735-751.

Spilt, J. L., Koomen, H. M. Y., \& Thijs, J. T. (2011). Teacher wellbeing: The importance of teacher-student relationships. Educational Psychology Review, 23(4), 457-477.

Toom, A., \& Husu, J. (2012). Finnish teachers as 'makers of the many': Balancing between broad pedagogical freedom and responsibility. In H. Niemi, A. Toom, \& A. Kallioniemi (Eds.), Miracle of education: The principles and practices of teaching and learning in Finnish schools (pp. 39-54). Rotterdam: Sense Publishers. 
Toom, A., Karvonen, U., \& Husu, J. (in review). Uncovering the relational characteristics of student teachers' professional agency. Submitted to Educational Research Review.

Turnbull, M. D. (2002). Student teacher professional agency in the practicum: Myth or possibility? Curtin University of Technology.

Turnbull, M. D. (2005). Student teacher professional agency in the practicum. Asia-Pacific Journal of Teacher Education, 33(2), 195-208.

Vangrieken, K., Dochy, F., Raes, E., \& Kyndt, E. (2015). Teacher collaboration: A systematic review. Educational Research Review, 15, 17-40.

Van Eekelen, I. M., Vermunt, J. D., \& Boshuizen, H. P. A. (2006). Exploring teachers' will to learn. Teaching and Teacher Education, 22(4), 408-423.

Veenman, S. (1984). Perceived problems of beginning teachers. Review of Educational Research, 54(2), 143-178.

Vermunt, J. D., \& Endedijk, M. D. (2011). Patterns in teacher learning in different phases of the professional career. Learning and Individual Differences, 21(3), 294-302.

de Vries, S., Jansen, E. P., \& van de Grift, W. J. (2013). Profiling teachers' continuing professional development and the relation with their beliefs about learning and teaching. Teaching and Teacher Education, 33, 78-89.

Vähäsantanen, K., Hökkä, P., Eteläpelto, A., Rasku-Puttonen, H., \& Littleton, K. (2008). Teachers' professional identity negotiations in two different work organisations. Vocations and Learning, 1(2), 131-148. 
Wolff, C., van den Bogert, N., Jarodzka, H., \& Boshuizen, H. (2015). Keeping an eye on learning: Differences between expert and novice teachers' representations of classroom management events. Journal of Teacher Education, 66, 68-85. 